\title{
12 \\ The art of struggle for free societies
}

\section{The art of complexity}

To be a serious social democratic leader in a democracy has always been demanding. You must make the tax system more progressive, build social housing, revitalise the welfare state, grow a more redemptive and inclusive education system, increase the minimum wage, reduce discrimination based on gender, sexuality, race, age, disability and more, shift the shape of the economy so people grow in a wealth of human services while shrinking their wealth in consumer durables and other activities that burn carbon and other pollutants, strengthen dozens of regulatory institutions, energise peace diplomacy, care for refugees, revive the United Nations and be advocates within it for nuclear disarmament, and more.

To be active social democratic citizens, however, in one sense demands much more than we demand of our leaders. Social democratic citizens must hold our leaders' feet to all these fires that could see them burned by entrenched interests. On top of that, we must keep social movement politics in good condition. We hit the streets to support youth leaders on 'School Strike 4 Climate' day. We are active in showing that Black Lives Matter and in resisting all manner of dominations and wars. In a second sense, active citizenship is not so demanding. It is a labour of love that sustains our souls. And we know we must not and cannot diffuse our energies into every cause. Rather, we select some concentrated contributions that matter, growing the hearts of activists who CHIME 
with Connectedness, Hope, Identity, Meaning and Empowerment. Good activism is like good scholarship in being a gift of joy that nourishes our being alongside our fellow earthlings.

The theory of crime and freedom is a theory of what to do to build a society that subdues domination and subdues crime. What is to be done? Such an enormous list has accumulated in the key propositions listed in Appendix I. There is so much to do only in making minimally sufficient deterrence work, just to enliven so many separations of private and public powers. Yet they are actually a long list of tributaries of practical work that give meaning to rivers of transformation. These rivers are:

- Reduce all dimensions of domination.

- Separate and temper powers.

- Strengthen institutions of the market, state and civil society, and strengthen individuals.

- Maintain a normative order that nurtures collective efficacy to resist domination.

- Strengthen financial capital, human capital, social capital, recovery capital and restorative capital.

- Prevent wars before they begin to cascade violence, anomie and domination.

These six rivers with all their tributaries then combine to form a particular flow for macrocriminology. This is the recursive flow of strengthening freedom to prevent crime and preventing crime to strengthen freedom. The many tributary propositions show what it means for freedom to be a wide and powerful waterway. Freedom is socially embedded in many not so minor flows of institutions. This vision is contrasted with thin liberal freedom. The argument is that thin liberal freedom perhaps helps in crime prevention, but only weakly, whereas thick republican freedom helps mightily.

My empirical analysis is complex about when and how crime is increased or decreased by wars, markets, states, civil societies, inequalities of different kinds, pluralised separations of powers, normative orders of diverse kinds and varied forms of capital. These structural features cannot be reduced to a small number of simple empirical understandings; the normative dot points are simple and sweeping, even as they are grounded in an empirical 
analysis that is complex. Because of that empirical complexity, the political sense-making of the six dot points will be radically different in different times, places and circumstances.

I hope readers who reject republican social democracy in favour of liberalism, socialism, or conservatism can still find the odd inference of value to them in this book, as well as some good issues for conversation and the waging of political contestation. While you do not have to be a republican social democrat to find value in the theory of freedom and crime, this is the political philosophy that gives coherence and direction to what is otherwise a jumble of propositions for a complex world. Rejecting republican social democracy just renders my long list of propositions devoid of its pretences of elegance, coherence or parsimony.

A paradox of what this book has accomplished is that it shows how a nuanced grasp of empirical complexity can motivate empirically informed normative inferences that are simple enough to be rallying cries for populist political struggles. A good example of this is the empirical understanding that most forms of inequality and poverty do not explain most crime most of the time, but that some form of inequality or poverty or discrimination helps explain crime (and war) most of the time. This empirical understanding motivates the normative inference to 'reduce all dimensions of domination', even when particular dimensions in particular circumstances do not explain crime or war. Hence, the art of complexity that averts policy paralysis by analysis is the art of putting normative propositions in conversation with explanatory claims and vice versa. Finally, I hope criminologists who believe normative theory is something scientists should not do will nevertheless find some empirical insights in the macrocriminological reframing of the field.

The final pages of Chapters 2 and 8 attempted to create the rudiments of a roadmap for quantitative researchers to begin to knock over the many unknowns to inform our understanding of what makes all these institutional tributaries flow. There is much for historians of crime and freedom to do. Great challenges lie ahead for ethnographers of crime and freedom. When that is done, many of my tributaries will prove to be creek beds that have run dry, particularly in nuanced application to contingent local institutional histories. New tributaries, however, may be found that run deeper to make crime prevention flow with freedom and freedom flow with crime prevention. 
In this work, criminologists should not be too humble that the work of political theorists of freedom is so much more profound than that of criminologists. The political philosophers, lawyers, economists and historians do contribute to grand intellectual challenges that give meaning to freedom. But if criminologists play their part badly, financial crimes will cause financial crises that might cascade to war. If they do not play their part in showing how to regulate environmental crimes, there will be ecocide. Surviving political philosophers will then be back doing their work in dark caves. If criminologists do not discover how to prevent cyberwarriors, cyberterrorists and cybercriminals from doing foolish things that destabilise weapon control systems, that polarise previously listening democracies into digital tribes that disengage from their enemies, genocide or ecocide awaits humankind. We may suffer an unintended nuclear war between India and Pakistan next year, or next century. It might cause an unprecedented impact on the ozone layer, a nuclear winter and famine for decades across the entire planet (Mills et al. 2014; Hess 2020) or there might be no global nuclear winter and only regional environmental impacts (Reisner et al. 2019), depending on whose model you choose to believe. Whatever was the correct assessment of the extremes of these risks during the 2010s, they are bound to be higher during the 2020s and 2030s as India and Pakistan expand the number and sophistication of nuclear weapons they are capable of launching. This book has explored a journey of belief that macrocriminology matters because it has worthy contributions to make to preventing ecocide and genocide and preserving freedom and democracy.

As the speed of missiles increases, panicked generals have fewer minutes to decide whether their screens reveal a false alarm or an imperative to use or lose their missiles. Gone are the good old days of the Cold War when nuclear powers had 30 minutes to decide whether to launch in response to the multiple occasions when false evidence of attack secretly shook the planet. Ecocide and genocide are preventable; criminologists have obligations to their descendants to get to work on crime-prevention projects that inspire hope with their relevance to these challenges. The next section discusses how criminological theory must become more adaptive to a dynamic world normative order with the example of AI crime. 


\section{Al crimes}

Control over Artificial Intelligence (AI) renews powers to dominate. AI enables crimes that leverage domination, as in control of swarms of killer robots on ground, air or sea. One standard answer to this risk is to say that ethicists as well as engineers must be involved in design of AI algorithms. Yet no one in the social sciences or in public administration ever felt it wise to entrust anything totally to ethicists. The insights of ethicists have great value, but must be checked and balanced by a galaxy of other traditions of understanding found across universities and societies that offer different kinds of insights about complex realities.

Algorithms are defined as sets of rules (usually procedurally sequenced, step-by-step sets of rules (for example, first do A, then if B, do not do $\mathrm{C}$, and so on)). All socio-legal scholars understand that the rule of law cannot work justly as a rule of rules that can be read off by one actor placing their lens upon complex realities to decide how a set of rules applies to a set of facts. Nor can AI work justly when decisions are made by one pre-programmed machine. A method for reconciling rules and principles is needed to render the rule of law just. This must be combined with a method of multifaceted dialogue between judges and prosecutors, judges and defence lawyers, defence lawyers and prosecutors, among different judges in appellate courts, among all these professional actors and witnesses, defendants and jurors, and in dialogue with legal scholars who reflect and write on long and paradoxical histories of case law. The more powerful are the actors contesting the interpretation of rules (as in corporate tax law, securities law), the more the body of rules evolves towards complexity and thickets of contradiction that allow the interpretation of one sub-set of the rules to evolve to challenge the logic of other sub-sets of the wider fabric of rules. Then the rule of law must be tempered with a rule of principles, dialogically applied. An example is Braithwaite's (2005b: 144-55) theory of legal certainty by transforming the relationship between rules and principles, and outside-in regulatory design.

The more AI succeeds in extending power, the more it will fall under the control of powerful corporations and national security states. This can mean computers gaming rules to advance the objectives they are programmed to pursue- be they profits on trades, or kills. A kindred 
evolution of algorithmic gaming and loopholing of complexity and contradiction will accelerate to render the wider fabric of the ethical rule of rules unserviceable. Propensities of machines, and of powerful actors who own them, to game rules requires more than tempering the rules by principles and by dialogue and appeals, as in the practice of the rule of law. Most defenders of AI will say that 'a regulator' is also needed. While that is definitely true, this book has shown that regulating corporations doing business actually requires hundreds of regulators. In the less complex business environment of the 1980s, Grabosky and Braithwaite (1986) studied 103 major business regulators operating in one country (Australia), without including international regulators in the study. The present book concluded that corporate and national security state power must be tempered by hundreds of separations of powers within institutions and between them. In addition to state checks and balances, AI domination must be tempered by trade unions, consumer groups, environmental groups, Citizens for Tax Justice, Shareholders' Associations, professions such as health, architecture, engineering, accounting, compliance professionalism, and more. They also need to be tempered by the work of parliaments, elections and referenda, by political parties, by a complex array of public service bureaucracies, which in turn are regulated by public service commissions and inspectorates, Ombudsmen, anti-corruption commissions, human rights commissions, by international law enforced by treaty secretariats, UN agencies, and other international institutions like the International Civil Aviation Authority meta-regulating flight by drones just as they do for piloted flight. In sum, we might want AI to be tempered by all the institutions discussed in this book, and for all these institutions to learn to adapt to this challenge. Therefore, it is facile to say that to avoid glitches AI should be regulated by 'an AI regulator'. We can assume that AI regulated by one regulator would be as large a folly as corporate conduct would be if regulated by just one corporate regulator. While it is too early to comprehend how criminal entrepreneurship in domination through AI will evolve, we might assume that most of the principles for tempering power to control organisational crime discussed in my 150 propositions will apply to AI crime, and that many extra principles will be needed that are AI-specific.

The military-industrial complex leads lobbying for unregulated AI as it gathers around itself well-funded ethicists it can live with. As we see with preliminary use of drone warfare in Libya and attacks inside Saudi Arabia, it can considerably destabilise and unbalance balances that serve peace. 
In time, the drone swarms may arrive to attack strategic laboratories on university campuses we love, mimicking the Israeli method of extrajudicial assassination of Iranian nuclear physics professors. However worried we should be by that risk, we cannot, should not, kill off the power of AI. Superior AI capabilities to detect cancer and detect fraud in carbon markets are urgently needed. AI constitutes new markets in virtue, new markets in vice, and new capabilities for extreme domination in ways that render most of the theoretical spadework of this book relevant.

National security states and the most richly capitalised corporations are the actors seizing control of the AI assets that most extend wealth and power. What this means is that AI creates a new frontier of hegemony. It therefore calls out a new hegemonic contest from civil society, for example to ban algorithms for killing human beings, criminalise them, socialise them as shameful. The key phenomenon to understand for those who care about freedom is exactly how does AI transform hegemonic settlements, exactly how, in detail, can AI power be tempered, and what should be the nature of struggle for a new hegemonic settlement. That is a topic for many books beyond this one. Because domination is voracious in the way it grows new modalities and frontiers of domination, the question of how to struggle for new hegemonic settlements to temper this expansion is a natural way of conceiving the central political question. Having illustrated its importance with the example of AI, this is the question that animates this concluding chapter.

\section{Peace and the local turn to freedom}

A problem with the approach of this book is that there is little prospect of achieving freedom and crime prevention during a civil war or a foreign invasion along any of the institutional rivers its chapters have followed. The second part of the problem is that it is unsatisfactory for me to keep referring the reader to another recent book with Bina D'Costa, another vast literature, on that part of the macro picture about how to pursue and moor workable institutions of peace. The fact is that there is much to learn from peace research concerning the limits of all 150 macro conclusions. Most wars and the war crimes that fester within them are rendered complex by many local cleavages that feed and transform master cleavages, often through joint action by local and supralocal actors (Kalyvas 2003, 2006). Civil wars are neither feuds writ large nor local 
manifestations of macro cleavages. Rather, wars are phenomena that, like crime, can only be pacified with justice, hotspot by hotspot, right across national-global landscapes. This is because wars spread violence through mechanisms of local, national and international cleavage and alliance.

What we learn about how to do peacebuilding well has lessons of more general import about how to struggle for better institutions. After Cambodia was ravaged by genocide, civil war and invasion by a foreign power, the United Nations could simply install a peace operation to build better institutions on its ashes. The United Nations did that with great success in consolidating peace with dramatic reductions in crime from the extreme levels of murder and theft that prevailed during the genocide, as discussed through the research of Broadhurst et al. $(2015,2018)$. The Cambodian peace operation, however, was a failure in institutionalising freedom. The legacy of war since 1985 has been one of despotism by a former Khmer Rouge communist battalion commander, Hun Sen, who defected to support the invasion by Vietnam. He institutionalised an authoritarian one-party state that pretends to hold free elections.

What we learn from peacebuilding research is that it does not work for the United Nations to march in and start building institutional superstructures of separated powers, such as a professional judiciary. It does not matter how well the United Nations trains the judges because the despot fires them if they act with genuine independence. We learn that the better strategy is to ask what institutional building blocks for the foundations of a better society have survived in the ashes or are beginning to sprout from them. This approach applies to the green shoots of the agonistic pluralism discussed in the next section. Without civil society contestation of hegemony, hegemony cascades horrors of domination.

This way of thinking is apt for judicial institutions. Peacebuilders, local and international, must ask themselves: 'What is already working around here to deliver justice and safety from violence for these people?' Wardak and Braithwaite (2013) and Braithwaite and Wardak (2013) concluded that in Afghanistan the answer was local tribal jirgas (assemblies of elders) and shuras (consultations). Survey research indicated that these were the local institutions that people most trusted for these purposes. The least trusted institutions were the state courts funded by international aid; their judges were corrupt and captured by the will of warlords or opium kingpins. The police were viewed as organised thieves. These USrun surveys showed that the Taliban courts were more popular and were 
seen (accurately) as less corrupt. But the most preferred justice was local justice under the stewardship of village or tribal elders that delivered jirgas and shuras (forms of restorative justice). They were deeply imperfect, dominated by male greybeards. We have seen how Ali Wardak and Ali Gohar's work is about different ways of bringing the greyhairs (female elders) into prominence in jirga justice (Braithwaite and Gohar 2014). Some local jirgas accept foreign aid to support their work with the string attached that they must empower greyhairs in the process. In other local contexts, this kind of foreign interference is spurned, but funding support for separate circles of greyhair jirgas is embraced by the women, and in time greybeard jirgas often reach a rapprochement with growing greyhair assertiveness. Peacekeepers and local police sometimes play vital roles in protecting these green shoots of justice reform, protecting them from men with guns who aim to uproot them.

While I will not re-summarise all the empirical experience and literatures traversed in Peacebuilding Compared, it is vital to make the point that a problem with my macrocriminology is that it is too much about institutional superstructure and too little about socially embedding foundations for them. I keep paying lip-service to micro-meso-macro linkages throughout this book, providing but a thin veneer of institutional texture and nuance to how that does or does not work from the bottom up. There is a need for ethnographic critiques of this book for its top-down deficits. I hope to do more of that in resuming Peacebuilding Compared fieldwork in new locales post Covid.

'Best practicitis' (Ramalingam 2013: 33) and evidence-based policy can be curses on good governance. They indoctrinate policymakers to persist with 'evidence-based policy' when it is demonstrably failing in new contexts. Best practice might work when local contexts are well understood-as Green (2016) explains in How Change Happens. Usually, top-down reformers and agonistic resisters alike do not understand local contexts well. Randomised controlled trials show that 'positive deviance' in development practice-for example, searching for deviant rural village practices of positive nutrition and encouraging modelling of these practices by others in the village-works. It works better than village education programs on nutrition best practice (for example, Bradley et al. 2009). This can be the positive deviance of a loved cook in their village or the agricultural practices of a respected local farmer. Positive deviance, again, is something that can work even though it is unknown or little understood by anyone from outside the village. It is radically variable 
because it is 'deviant' (Green 2016). In part, positive deviance works by the power of model-mongering and localism. In part, it works because it appeals to tastes adapted to unique circumstances. It energises because someone in the community has identified the solution, so it focuses on their assets and knowledge rather than on their deficits compared with a 'best practice', which tends to come from the North Atlantic.

The idea of positive deviance can be scaled up from the village to macro projects of transformation like China's, for good or ill! The Communist Party of China could be interpreted as adopting what is, from its point of view, a positive deviance approach to Confucianism. Under Mao Zedong, Confucianism was seen as ruling-class feudal thinking that had to be stamped out. This century, the party leadership concluded that half a century of stamping it out had failed, so they shifted strategy by asking themselves what are the good aspects of Confucian ideology for creating the harmonious communism they crave after their rejection of Mao's divisive Cultural Revolution? Second, they sought to revitalise the paternalistic bond between citizen and state that in Confucianism is modelled on the bond between a dutiful son and a father (Tu 1998; Ebrey 1991). Reframed in this way, Confucianism is now back in China, taught in schools again.

The discussion of Sun Yat-sen's constitutionalism and of Dennis Wong's (2014) advocacy of the suppression of Confucianism's Three Bonds and promotion of its Five Norms had a purpose. That was contestation of the Communist Party's appropriation of Confucius with a civic republican appropriation of Confucius. While the West can learn some good things from Confucius, Sun Yat-sen and Dennis Wong, any project of finding 'positive deviance' in Confucian practices that prevent crime and domination is, of course, bound to have more resonance in China than in Europe. That is fine because what has resonance in East Asia is more important than European resonance. This is not only because there are so many more East Asians than Europeans. It is also because East Asia is more important to preventing ecocide than Europe-with China accounting both for more carbon and for several times as much investment in green technological innovation as Europe (Drahos 2021), and even Japan accounting for about as much investment in renewables as all of Europe (Braithwaite 2020a). Europe is important, too, especially through the diplomatic bridge it is best placed to build between China and the Americas. The risks of triggering an accidental nuclear genocide that 
could wipe out all freedoms and all civilisations with a global famine are bigger from East Asia than from Europe. That also makes questions about what resonates in China, the Koreas and Japan of special importance.

This attempt in the present to be less pathologically western than in my past is still limited. The aspiration of evidence-based western social science to reveal 'what works' is a common criminological pathology compared with more eastern and southern searches for positive deviance in what is already working better in particular spaces. We should relish the paradox of randomised controlled trials that show positive deviance is 'what works' better than evidence-based application of 'what works'! A local turn away from best-practice universals is crucial to the art of freedom.

We can learn from Tom Scheff (1990) that the macro-methodology of freedom is abductive. It involves induction from a grand canvas, from a pointillist painting of a map of the planet, with a bright dot here from a jirga of greyhairs under fire from Islamic State in Afghanistan, another bright dot in Rolpa, Nepal, where feminist Maoist peasants develop their proposals for a feminised postwar constitution, another in a restorative justice training course in which New Zealand Prime Minister Jacinda Ardern soaked up Polynesian wisdom about how to heal and prevent violence, an AA meeting in a Christian community from which wounded healers fan out to scale up collective efficacy and recovery capital for substance abuse by gang foot soldiers, war crime trials in Colombia in which a military commander from the Revolutionary Armed Forces of Colombia (FARC) and a state general confess their crimes and undertake as sentences five-year programs of dangerous work clearing mines to protect the next generation of children.

While there is so much contextual diversity in the bright colours of each dot, the inductive method is to look for macro-patterns in the dots of positive deviance, and deviant swerves away from domination. We can watch especially for dots that become ink spots expanding to connect to other ink spots of freedom to flow across a landscape of liberation. Then we must shuttle from such induction to deduction: on peacebuilding, yes, we need the United Nations and we need to temper its power to make it stronger. This tempering and strengthening include vernacularising lessons from local dots of wisdom (Merry 2006). The United Nations has a major role to play in scaling up mine clearance across the planet. One of the things it can do to make us freer from violence is persuade war criminals to tell us not only where the bodies are buried, but also 
where the mines are buried, and to self-incapacitate the planting of more. While I apologise for a book that is too heavily weighted towards topdown deductive institutionalism and too light on embeddedness, I am unrepentant about how important the macro-institutional superstructures are. My remorse is about insufficient micro-texture in how I have shuttled between deduction and induction.

\section{For agonistic pluralism}

This book has certainly argued for big savings in state expenditure through release of 90 per cent of people currently in prison. It also argues for shapeshifting the economy from goods to services through huge increases in state and community expenditure on a great variety of institutions. More tax, environmental and other regulatory inspectors; greatly expanded health, welfare and education budgets; and radical redistributions of wealth and power are particularly important. Australia can shapeshift to grow its recycling sector, which currently generates 9.2 jobs per 10,000 tonnes of waste, compared with only 2.8 jobs for the same amount of waste sent to landfill (Beringen 2021). At the time of writing, the world needs a post-Covid care-led recovery with more investment in state funding for child care that becomes more educative and enables more women to work who want to, care-led restoration of the land and the environment, restoration of an aged care system that has been ravaged by Covid and state neglect, and total elimination of extreme poverty by education and health guarantees, social housing (Braithwaite 2021b) and a participation income (Atkinson 2015; Quiggin 2019). The next section argues that this kind of institution-building grounded in institutional anomie theory is desirable not only for freedom and crime control, but also for the survival of species on this fragile planet. That does not mean it is politically feasible to do it. The agency of all species ultimately finds it impossible to prevent themselves from becoming extinct.

A fair criticism of the book to this point is that it articulates no theory of power and politics that might inform grappling with how elites resist so many of the ideas in the book, however essential they might be to human freedom and flourishing. Critics will say all it has is a criminological theory of how to escape the deterrence trap, the compliance trap and the retribution trap and a commitment to transform republican and social democratic politics to accomplish long lists of reforms. It does have more 
than that to say about political strategy. Yet the thrust of the criticism is fair that its political strategy is not up to transcending my defeatism in suspecting that human civilisations will be destroyed in an unintended cataclysm in the next century or two. The hopeful paradox here is that the very crises with known risks for taking us to the brink are the kinds of near-crises that can bring about the agonistic struggles discussed in this book. These struggles might prevent crimes of reckless civilisational suicide triggered by genocidal nuclear conflict or climate catastrophe.

How might we think more deeply about these dangers and alternative politics of freedom? We cannot rethink the institutional domain without energising the democratic. We cannot avoid stirring political passions in a renewed way. This renewal must be different from the way the right mobilises affect through a populism that is about nationalist and racist exclusion and the exclusion of a narrowed kind of criminal class. Technocratic institutionalism, in which contemporary criminology is mired, opens the door to the unfreedom of exclusionary populism. Mouffe could equally be critiquing the professional criminology of experts (Loader and Sparks 2013) when she chastises the Third Way as a 'technocratic form of politics' freed of partisan confrontation in a supposedly neutral management of public affairs (Mouffe 2018: Introduction).

In spite of confessing to being a card-carrying social democrat, I am attracted to Chantal Mouffe's (2005: 56-63, 2013, 2018) 'post-socialdemocratic' critique of Third Way social democracy. That critique targets the writing of Anthony Giddens and Ulrich Beck, for example, and the political practices of Tony Blair, Bill Clinton and Barack Obama. Blair in important ways consolidated hegemonic terrain conquered by Margaret Thatcher, and the Clintons consolidated a hegemony of Wall Street and rentier capitalist inequalities installed by Ronald Reagan and affirmed with Clinton's 'it's the economy, stupid' brand of politics. Thatcher boasted that Blair was her greatest accomplishment—something with which Blair seems to agree. In light of everything said about republican imperatives to regulate Wall Street and the City of London, to rebuild public support for welfare housing, to make the tax system more redistributive, there can be no attraction to the stewardship of these institutions by many so-called social democratic regimes of recent decades. Mouffe reasonably sees ideological surrender to neoliberal thought in Third Way social democracy. That Third Way found virtue in keeping taxes low, governments small, unions weak and markets liberated as inevitabilities that social democrats must accept. This is not to say that civic republicanism is on the same page as 
Mouffe's post-Marxist thought in many respects. I was never attracted to Marxism and always to markets, but always wanted more richly and deeply separated powers within and against states and markets to check and balance their dominations.

Where Mouffe and I are on the same page is in rejecting Third Way social democracy that is captured by finance capital. We are also at one in rejecting the left's disengagement from projects to transform state institutions that we see in the thinking of some theorists and activists of developments such as the Occupy Wall Street movement (for example, Negri and Hardt 2000). Leftists who want to drain the swamp will bequeath us undrained swamps and unregulated malaria just as surely as will rightist swampdrainers. Like Mouffe, I argue for a politicised social science that engages with projects of state, market and civil society transformation to begin the process of repairing the problems that flow from crusted hegemonies, but particularly the hegemony of finance capital. We have also seen that the hegemony of monopolist tech giants backed by potent state sponsors is a threat emerging as a rival domination to finance capital.

Like Mouffe, I do not think populism need be a dirty word for what should be a wholesome politics of the people confronting oligarchy or, as Laclau (2005) sees it, the 'underdog' resisting 'those in power'. Populism should not be gifted to the right by the left because the left thinks it should be dispassionately technocratic rather than passionately political. While the kinds of institutional projects advocated in this book attempt to be evidence-based and technocratically wise, they cannot be progressed without engaging the passions of democratic politics. This means social movements, the women's movement, postcolonial struggles, the labour movement, the environment movement, the human rights movement and social movements that are more specific but particularly strategic such as Citizens for Tax Justice, the social movement for restorative justice and our 'jailing is failing' movement of the Justice Reform Initiative. Engagement with such social movements has been meaningful in motivating me. I commend that path to young scholars and hope it enriches them.

Many of our most insightful criminologists today cultivate circumspection about populism as inherently dangerous. Russell Hogg (2013: 118), with Laclau, cautions against excising the insurgent crowd from history and from political theory, and offers these thoughtful reflections on the writing of Sparks: 
Richard Sparks argues that we should not (as others have done) see managerialism and populism as competing trends or influences, but consider the possibility that a populist political rationality and an administrative rationality can be mutually necessary and simultaneously in play: one operating in the political foregroundthe domain of representation - and the other backstage-where the logic of pragmatic, managerial calculation prevails. If Sparks is correct, one reason for the struggling political fortunes of the left is that it has become suffused by a rationality of politics as administration and is seemingly incapable of articulating a credible, progressive political vision.

It is hard to imagine a hegemonic shift in China away from the politics of domination in criminal justice, toward more democratic settings with tempered, separated powers, without insurgent crowds playing a significant political role. Our political imagination can go to scaling up participation in the restorative circle as a micro-platform for a future where marginalised Chinese youth learn how to be democratic because restorative circles tend to be an overwhelmingly popular experience among participants (Braithwaite 2021e), and in China restorative reforms have already helped reduce incarceration rates (Zhang and Xia 2021).

A message for criminologists has been that if you wish to be more than just scholars and to be politically active, the best way might not be law reform tinkering (even though that can be helpful); it is to be an active feminist, a peace activist, a First Nations' rights activist, a welfare rights activist, a tax reform and environmental activist and a campaigner against criminalised corporate dominations of markets and states. Criminological activism in these social movements has helped persuade citizens to be more concerned about the corporate crimes of Big Pharma and banks, about the patriarchal crimes of men against women, about war crimes, and more. Agonistic contestation can only be effectively counterhegemonic for Mouffe if it connects to identities, projects and discourses that resonate with people affectively.

One contribution has been to argue for averting stigmatisation as crucial to resonating effectively (Braithwaite 1989, 1995; Ahmed et al. 2001). Many violent men in Australia, for example, reject their feminist rejectors as man-haters. Australian feminism in general eschews the stigmatisation of men. It manages to communicate disapproval within a continuum of respect. Occasional stigmatic excess, however, has been fuel for the fire of the patriarchal authoritarian right, which does so much damage by sustaining moral ambiguity about gendered violence. 
Historically, hegemonic inequality has allowed all manner of crimes of domination to thrive because powerholders have been able to sustain immunity from community disapproval. Reintegrative shaming theory is useful in showing how a society of censorious individualist busybodies can be profoundly counterproductive, while social movement shaming of structural evil can be transformatively productive. It shows why cancel culture was a passing fad that lit no road to freedom; cancel culture wanted for redemption and eschewed the grace that is the better path to nondomination and nonviolence.

Mouffe has clear thinking on the imperatives for these movements to achieve outcomes that fall far short of conquering hegemony. Rather, the purpose of political struggle is occasional victories that reset a new hegemony that is somewhat less dominating and freer than the one it replaces. 'Society is always divided and discursively constructed through hegemonic practices' (Mouffe 2018: Ch. 2); hegemonic practices are 'the practices of articulation through which a given order is created and the meaning of social institutions is fixed' (Mouffe 2013: 13; Laclau and Mouffe 1985); 'any order is of a hegemonic nature, i.e. it is always the expression of power relations' (Mouffe 2013: 7). According to this approach, nevertheless, 'every order is the temporary and precarious articulation of contingent practices'. Major change becomes possible at regular conjunctures (Mouffe 2013: 14). In macrocriminology, these conjunctures are anomic crises of disorder on the streets, wars, ecological crises and financial collapse. The formation of an antislavery movement, a trade union movement, 'first-wave' feminism and an environmental movement were also important conjunctures constructed from below. There is no final point of arrival at a society freed of domination. But crises are conjunctures that enable a reset from one vulnerable hegemony to another that might open a better pathway for life on the planet to survive its own violence.

There is massive variation between the kind of hegemony that exists in China versus hegemony in the United States, versus that in New Zealand under Jacinda Ardern. Mouffe finds virtue in imperfect struggles for the less-dominating hegemonies that create more space for liberty and equality. At the same time, Mouffe believes in agonistic pluralism whereby even though social movements struggle for the more benign hegemony of Ardern's New Zealand in preference to Trump's United States, it remains imperative for plural social movements to position Ardern's regime as an adversary flawed by diverse failures to tackle domination. An adversary 
in Mouffe's language of pluralistic agonism has certain ideas that should be contested but is not an 'enemy' to be destroyed as in the language of 'antagonism'. Furthermore, adversaries must not be seen as irrelevant, as in some discourses of anarchic disengagement from state institutions. Mouffe rejects liberal theorists' imaginaries of politics as a field where different groups compete to occupy positions of power. There is no appeal in the objective of displacing others from a seat they might take 'without putting into question the dominant hegemony and profoundly transforming the relations of power' (Mouffe 2013: 19). Politics is about agonistic questioning more than competition among elites. Practitioners of agonistic pluralism advance counter-hegemonic struggles for ideas 'under conditions regulated by a set of democratic procedures accepted by the adversaries' (Mouffe 2013: Ch. 1). Something in common is needed among citizens of a polity: a framework of 'conflictual consensus' that is a precondition for agonistic contestation to flourish.

Mouffe conceives of Hannah Arendt's and particularly Jürgen Habermas's ways of thinking about the rule of the people and the rule of law as fundamentally misguided in the character of their advocacy of deliberative democratic consensus. There is no enduring consensus around the new articulation of institutions settled after a partially successful counter-hegemonic struggle for institutional transformation, just a new hegemonic formation, a revised benchmark of hegemony to contest in the next struggle of agonistic pluralism against domination. Agonistic struggle proceeds with a politics of hope that '[e]very hegemonic order can be challenged by counter-hegemonic practices, which attempt to disarticulate the existing order' (Mouffe 2013: 124). This is another way of formulating the paradox of destabilisation rights as necessary for a less anomic social order, as discussed in Chapter 8.

While I agree with Mouffe on this at the level of macro-institutional politics, at the more microlevel of institutions, I throw in my lot with deliberative democracy theorists. Hence, as explained in previous chapters, the aim of a restorative justice conference is an undominated dialogue that leads to a workable consensus - not one where everyone feels they got exactly what they wanted, but one where they feel 'that's good enough for me' (to quote Tim Chapman, who in turn quotes Northern Irish victims from restorative conferences). Chapman means they believe their perspective has been listened to and taken seriously and they accept that the other perspectives in the room likewise had to be fairly accommodated in the final conference outcome. When the deliberative democracy of the 
restorative circle fails to reach a workable consensus, the matter is settled in the more adversarial justice of the rule of law interpreted by a judge. Moreover, representative democracy should be more deliberative than it currently is at the microlevel. University councils, faculty meetings or the cabinet of an elected government should make decisions via undominated dialogue and, if they can, reach the kind of workable agreement described above for a restorative justice conference. If they cannot, the alternative becomes, first talk, then vote (Goodin 2008). Then the losers of the vote return to the contestatory politics (Pettit 1997) of agonistic pluralism.

The agonistic politics of struggle for more equitable taxation is an example of a marginalised struggle, yet one punctuated with moments when social movements like Citizens for Tax Justice have some influence in reshaping new national and even global tax orders (van der Walt forthcoming). One new conjuncture arrived with the election of the Hawke Labor government in Australia in 1983. I worked with Treasurer Paul Keating on a small committee of business and civil society leaders from the 1983 National Economic Summit (which had more than 100 participants) to move forward the summit's agenda by establishing a 16-member Economic Planning Advisory Council. As the CEO of an active NGO, I was selected by Prime Minister Bob Hawke as a civil society representative on the council that met with the prime minister and other national leaders from government, business and trade unions for at least one full day every month. Hawke was a reformer, though a liberal rather than a left-wing Labor leader, but he had enormous strengths in nurturing deliberative processes that could work meaningfully in a room of 16 people. A rare day of counter-hegemonic progress arrived in 1985 when Hawke and Keating (who succeeded Hawke as prime minister in 1991) announced they were minded to propose options for new taxes on wealth and/or capital gains at the National Tax Summit (another summit of around 100 people). The business leaders on the council insisted this was a bad idea. That was expected and cut little ice with a government that was also willing to cut company tax as part of the reform package. The most politically energised resistance in the room came from the head of the National Farmers' Federation. He made good points about how Australian agriculture on our big brown land could only be internationally competitive if farms were massively larger than in other countries. A problem with taxes on death or wealth would be that in times of drought when the only wealth left was the value of the land that was being taxed, the sole path to paying the tax would be to break away a parcel of the land, reducing agricultural efficiency. 
Hawke then said that he wanted him to assume that the government was so strongly determined to introduce some sort of tax on wealth or capital that farmers had no hope of stopping it. If the prime minister then gave him the opportunity to design such a tax in a way that would minimise the breakup of family farms at moments of intergenerational inheritance, how would he design it? What we had here was a long-term agonistic struggle over taxes on wealth and capital that reached no deliberative consensus at this moment of Australian history, nor at any point since. Yet there was meaningful deliberative democracy in the micro-conversation of the 16 council members. The council made some useful progress in understanding what might be more destructive forms of tax for the comparative advantage of Australian agriculture. On this and other issues that arose during my four-year term, the council provided many useful moments of microtimeouts from agonistic politics of the social movement variety. The main game remains one of agonistic pluralism, but micro-moments of consensusbuilding around a table on particular issues have a worthy place in a sensibly hybrid democracy. Other moments are about softening up in faint hope of future consensus-building moments. An example from that 1983-87 term was softening up business, trade union and political leaders to accept why a carbon tax would be in the long-run interests of business, workers and governments. This was not at all agonistic; it was smiling banter about my crazy ideas that everyone knew would go nowhere in the 1980s. I would send them copies of 1980s economic publications on carbon taxes; they would return them with pleasant jibes to humour me. Thirty years later, after the secrecy of cabinet minutes was lifted, I learnt that the Labor Cabinet actually discussed a new carbon tax as a way of managing its fiscal deficit. It was rejected but had attracted support from a substantial minority around the table.

The deliberative democracy of the workplace meeting, the kinds of safety committee meetings in mines and of residents' or relatives' councils in care homes much discussed in this book can offer a hybrid of microdeliberative democracy. They can be combined perhaps with some citizen participation in deliberative polling processes that elected politicians take seriously, ${ }^{1}$ with deliberative democratic participation in the local branch of

1 I do agree with Mouffe (2018: Ch. 3) that because deliberative polling is an individualised form of politics, it is not as important as the contestation of collective projects. Then, as long as deliberative polling does not displace collective political contestation, it can add some richness to the deliberative texture of a hybrid political order. It also empowers individual agency structurally if a large proportion of the society gets their turn to shape politics in this way. 
one's chosen political party, and other hybrids. At the macrolevel, a hybrid of representative democracy, contestatory democracy and agonistic pluralism can be the light on a social democratic hill. Agonistic pluralism can be energised to contest the way these other forms of contestation fail to work in a representative democracy. All these other forms of hybrid democracy and all the separated powers of local society, business society, national society and international society have parts to play in the contestation. It is important not to believe that the only game, or the main game, of agonistic pluralism must be contesting the decisions of elected governments. A Mouffean hybrid of micro-macro democracy averts the dangers of technocratic sanitisation of democracy that kills off passion for progressive politics. Technocratic governance leaves populism in the hands of authoritarian populists who threaten new eras of political domination (Mouffe 2018). While we have seen that authoritarian capitalism has been on the rise in recent history, from Moscow and Beijing to Dhaka and much of the West, so are agonistic social movements led by the young; the latter are the republic's remedy to the former.

Ordinary people can enjoy a less alienated life if they experience some real influence over how their part of their workplace is run, how their school is run, how their child is sanctioned if they get into trouble with the police, how their parents are cared for in an aged care home, how an environmental group they are passionate about sets its priorities and even how the political party of their choice makes decisions at the local level that bubble up local political impulses to higher echelons of the party. This is not to say that to be a good citizen you should get active in a social movement, a political party or restorative justice conferences. It is just to say that we should want enough people to get active at these levels for the democracy to energise and accomplish a progressive populism that resists authoritarian populism. Second, we should want all citizens to be able to avail themselves of the opportunities for agonistic contestation in forums of these kinds that matter to them most. Then they can become citizens with the social capital of Connectedness, Hope, Identity, Meaning and Empowerment in a democracy that CHIMEs. CHIME might have technocratic roots in meta-analysis, but it implies more opportunities to jump in and get meaningfully politically active. Moreover, democracy that CHIMEs should begin with children learning how to be democratic. This book has argued that restorative justice in families, schools and the justice system can contribute to learning how to become agonistic pluralists. It happens when restorative justice delivers a 'that's good enough for me' outcome rather than perfect healing. 


\section{Ecocide and genocide as likely futures}

There are aspects of contemporary hegemonic formations that are existential threats, as well as threats to freedom. If criminology in universities can discuss politically creative ways of confronting and contributing to turning back existential threats that are such a heavy burden on the very being of young people, criminology can be found to have something to offer that is appealing to students who seek to make a difference. Criminology might take pride when some of its students sally forward to be leaders of social movements for counter-hegemonic transformation. Of course, all political traditions should flourish in a university. Criminology will never have many of the answers to questions about how we might build a future society together that is free from threats to the very existence of our fellow species and our own. Throughout, this book has attempted, nevertheless, to uncover more ways in which criminology might contribute to saving the ecosystems of this planet from cascading past tipping points.

\section{Insufficient environmental enforcement}

Much pathbreaking research is done on environmental enforcement. Yet Edwin Sutherland would be disappointed by what a low proportion of excellent environmental compliance research is undertaken by criminologists. The deterrence of environmental crime is not minimally sufficient (Chapter 9) and incapacitation (Chapter 10) is even more woeful. Chapter 10 discussed the historically amazing self-incapacitation accomplishments of aviation safety in reducing fatalities, as documented by authors like Wilf-Miron et al. (2003) and Hodges (2015). For all that, we must also see that air travel is insufficiently deterred for the environmental damage it does. International flights are the great carbon guzzlers of the world of travel. I put much less carbon into the atmosphere in a year of driving my 14-year-old car than in one economy international flight from Australia to the northern hemisphere. Travelling business class takes up twice as much of the space on the flight and twice the share of the flight's carbon emissions. Carbon screams for a higher price so that the cost of that international travel might double or triple, so I am deterred from doing too much of it and so airlines are motivated to move to flight powered by renewably produced hydrogen, for example. Chapter 10 discussed the stunning work of the coal industry in reducing fatalities. 
But, really, carbon today must be priced at a level that deters mining companies from digging it up at all or, if they cannot be deterred by the market, incapacitates them by corporate capital punishment.

In May 2020, the operating company of the Hazelwood Power Station in Victoria's Latrobe Valley, Australia, and the open-cut coalmine that fired it was fined $A \$ 1.9$ million for occupational health and safety and environmental protection offences associated with a terrible fire that ignited the massive mine. The mine's pit had an 18-kilometre perimeter. The major corporate owner and operator of the mine was the largest private-sector energy corporation in the world, the French company ENGIE (formerly Suez, which built the Suez Canal). It had revenue of A $\$ 83$ billion in the year before sentencing (2019). Most estimates of the cost of the fire to the nearby town of Morwell were more than $\$ 600$ million. So, was a fine of $\$ 1.9$ million minimally sufficient (Chapter 9)? One of the things environmental activists in Morwell wanted was at least $\$ 10$ million in seed funding to start a large solar farming industry in Morwell to replace employment in coal with jobs in renewables. They did not get this out of a sentencing process that took seriously none of the restorative justice principles discussed in Chapter 9.

The more fundamental point here is that this mine and its power station should never have existed. Regulation should have revoked its licence decades ago. This never happened, but mercifully, self-incapacitation did, when ENGIE, pursuant to a new policy of shifting energy production to renewables, voluntarily closed both the power plant and the coalmine in 2017. Corporate power ultimately took the most decisive step towards repairing harm after state regulatory power endlessly failed to do so. This was a mine that was always going to have this kind of catastrophic fire one day. During the life of the mine, the number of fires that broke out and triggered regulatory notification was reduced from 250 a year to $100-$ still an unacceptable risk. But more fundamentally, this brown coal plant was one of the dirtiest electricity plants in the entire world. It should have been escalated to responsive state incapacitation many years before the voluntary self-incapacitation of closure occurred, with the blowing up of the smokestacks televised. 
A reforming new Paris-based CEO, Isobel Kocher, was appointed in 2016 to transform Suez to become ENGIE, a greener organisation that shifted its investment to renewables. ${ }^{2}$ It was Kocher who took the decision to decommission the Hazelwood plant and mine in 2017, to sell the nearby Loy Yang B brown coal power station in 2018 and to announce on the company's website an intent to close or divest 'all emissions-intensive coalfired power generation facilities'. This induced internal conflict on her board; she was replaced in late 2020. A good restorative strategy would have been to ask Kocher during this 2016-20 window of opportunity to come to meet the citizens of Morwell, rather as the ACCC did in its early restorative justice cases in the 1990s (as discussed in Chapter 10). Morwell activists could then have made their pitch to Kocher for ENGIE to fund $\$ 10$ million or more towards their massive solar farm development and other new green employment opportunities in Morwell to compensate for the impending loss of jobs from the community's historical commitment to coal. This was the kind of project that interested Kocher; she opened a large wind farm in Australia in 2019. It would have been a good kind of innovation for the prosecutor or the judge to enable a restorative encounter with the CEO long before conviction and sentencing to allow an agonistic pitch from the people of Morwell to Isobel Kocher to start funding that green investment that was so aligned with her values and her company's new corporate strategy at that historical juncture.

A restorative corporate law imagination requires conversations with reformers inside corporate wrongdoers to open the door to the contestation of big agonistic and restorative ideas. It is a tragedy for Morwell and for the planet that such a conversation was not attempted at Hazelwood. The reason was a misplaced fear of being anything less than totally punitive towards the corporate offender. Precisely what Morwell needed was massive investment in renewable energy jobs by investors with pockets as deep as ENGIE's and with support from all levels of Australian government for a renewed Morwell.

2 In August 2020, the ENGIE website explained: 'What are we doing? Inventing a new reparative growth model. At ENGIE, we are convinced that "the common good is good for business". Our role as a leader in the zero-carbon transition is to show that this necessary transformation creates value and that it can combine performance and the common good. To live up to this ambition, we rely on the commitment of the Imaginative Builders community, formed by the Group's employees and all those who work with ENGIE (cities, startups, suppliers, NGOs, students, customers, etc.). This is why ENGIE is offering its customers a new approach to support their progress towards the challenge of a zero-carbon transition. Unique on the market, our "as a service" approach aims to make the zerocarbon transition accessible through integrated, tailor-made and co-financed solutions.' (Available from: www.engie.com/en/news/engie-positive-impact-strategy). 
Chapter 10 discussed the hundredfold reduction in safety risks achieved in nuclear power plants. Even so, another century of production delivers to our dear earth the risk it faced during 1986, when Chernobyl put the planet on the brink and killed an unknown, extremely large, number of people. And every year even the safest of nuclear plants produces nuclear waste that will still be with us when humankind becomes extinct. The Fukushima disaster showed in 2011 that tsunamis can be a megarisk of the longue durée to nuclear plants. Again, the nuclear industry may present such a risk that anything short of total incapacitation is insufficient - a dispensation the majority of societies have settled on by deciding not to build any nuclear power plants or to de-license existing ones. The United Nations has demonstrated that it can reduce the risks of ecocide through climate agreements. It has demonstrated it can greatly reduce war and crime and increase freedom through small investments in peacekeeping (Walter et al. 2020). Therefore, study of the impact of the United Nations on crime and freedom rivals the centrality to macrocriminology of the study of states.

\section{Ecocide and Green New Deal politics}

Some criminologists today write about the imperative to mirror the ultimate crime of genocide against our own species with a crime of ecocide against many species (Zierler 2011; Higgins et al. 2013; White and Kramer 2015; Pali and Biffi 2019). This is motivated by evidence that late modernity has already seen the extinction of 680 vertebrate species and thousands of invertebrates and a million species now face extinction risk (IPBES 2019). It is an ethical duty of criminology to make a better contribution to how environmental enforcement policies can stem the tide of extinctions before it cascades to human extinction. The big insights of this book about how to reshape the institutions of regulation, enforcement and state and corporate accountability can be combined with growth in the institutions of welfare to help prevent ecocide. To pick up Chantal Mouffe's theme, the current hegemonic formation is on a trajectory that leads to the extinction of the hegemons. This makes it a less resilient hegemony than reformers have tended to think. In a more immediate way, a megacorporation like ENGIE can realise after a disaster like Hazelwood that it is on a faster path to corporate extinction than it realised if it keeps feeding coal into power plants. Its survival path is to step up massively its investments in renewables. We have seen that BP confronted this survival shift after its Deepwater Horizon fiasco. 
A US path to survival is to help avert the extinction that could come from an unintended escalation to a nuclear weapons exchange with Russia or China by building cooperation with them on new regulatory technologies to avert ecocide (Drahos 2021; Braithwaite 2020a). Chinese and Russian paths to survival are collaboration with the United States on a global Green New Deal. Part of what needs to be done to that end is to make the United Nations more effective in preventing crime, war, ecocide and genocide by tempering the veto of the great powers. PostCovid, we can see that a World Health Organization with strengthened institutional capacities can help prevent global economic crises and the authoritarianism and therefore wars they might cascade to. The United Nations has demonstrated it can reduce the risks of ecocide through climate agreements (for example, closure of the ozone hole). We saw in Chapter 7 that strategic social movement activism can deploy strategic trade theories to divide and conquer ecocidal states and markets and slavetrading states and their markets.

While slave-trading is by definition a market in the vice of domination, this book has not generally been prescriptive in defining lists of markets in vice and markets in virtue. That is a topic for another book. The focus here has been on more meta-conclusions about the importance of agonistic contestation of what citizens should contest as markets in vice, and how. However we define vice and virtue, the globalisation of markets has proliferated both markets in vice and markets in virtue. Globalisation has also driven a race to the bottom in regulatory standards to control certain markets in vice, with states competing for investment by promising less onerous demands on business. This race to the bottom has been an especially large problem in driving down tax collections from corporations. At the same time, we have seen that organisations like Citizens for Tax Justice and Oxfam have had their victories in contestation for a more equitable tax system (van der Walt forthcoming).

Strategic trade accomplishments involve a social movement persuading a hegemon like the United Kingdom to ban the slave trade. Then the social movement levered British strategic trade interests to coerce other states into levelling the playing field in their plantation economy competition with the United Kingdom by also banning their slave trade. Working ratchets up at different levels is a totally different way to defeat markets in vice with markets in virtue. For example, when President Trump came to power and refused to implement the Paris Climate Agreement, social movements got to work with campaigns for states, cities, corporations 
and universities to make their own Paris commitments. This means that when the national ratcheting up of standards has broken down, lower levels can be ratcheted up. At a later date, this will increase the pressure on and possibilities for the national ratchet to get moving - and vice versa: in periods of history when the corporate ratchets for regulating markets in vice are stalled, national ratchets can move up with reasonable hopes that this will get corporate ratchets moving again after a lag. When that happens, even President Trump in his strategic trade competition with China could find it helpful to use these accomplishments of lower-level US ratchets to attack China for putting more carbon into the environment than the United States. When Trump did this, he was being an agent of the social movement for climate change, just as Ronald Reagan was more profoundly so in lobbying for the Montreal Protocol after US business had been forced by its environmental movement to be an early mover in banning chlorofluorocarbons. Meanwhile, the European Union was a more virtuous strategic trade actor that was negotiating trade agreements with China that committed the EU and China to bigger loops of ambition than Trump's United States. Both loops bore promising fruits of EU and Chinese commitments at the 2021 Glasgow climate meeting.

Social movement accomplishments like the Forest Stewardship Council (FSC) sought to put ratchets in a sequence. That is, the institutional design was that if the standards in a provincial or a national law went up, the FSC standard went up. If the International Organization for Standardization (ISO) 14001 voluntary international standard went up, the FSC standard ratcheted up. Furthermore, there was lobbying for 'continuous improvement' approaches within all of these regulatory ratchets so that the ratchets in series would be one-way, each constantly driving the other towards upward movement. None of these continuous improvement ratchets worked smoothly and often they worked badly. They clunked agonistically, with business lobbyists constantly throwing spanners into the works. More fundamentally, the coverage of the FSC remained small; most business opted out and forests continued to disappear. It is not the purpose of this book to evaluate such particularities. Readers can go to the johnbraithwaite.com website to search the word 'ratchet' to find accounts of global continuous improvement ratchets in series on nuclear power plant safety and many other domains in e-publications. The purpose here is only to show that there are social movement strategies of agonistic contestation that at conjunctures of crisis can deliver small or large victories. 
Serious intellectuals such as Robert Reiner (2020) like to say it is easier to imagine the end of humankind than the end of capitalism. Yet Reiner also points out that social democrats want more than Blair and Obama's Third Way and less than the end of capitalism. They want radical transformation along the lines of the opening paragraph of this chapter. My argument has been that critical junctures of crisis do make this transformation possible, and therefore human survival is possible.

Even the world's most powerful banks supported extreme Keynesian pump-priming and a surging regulatory welfare state in 2008 and 2020 (Levi-Faur 2014; Braithwaite 2021c) and turned off many investment taps to carbon. That was because bankers were the biggest beneficiaries of this momentary surge of regulatory welfare capitalism. Within variably short spaces of years after 2008, they were off life-support, making massive profits again. Then banks captured state policies to shift back to austerity, to substitution of debt (to banks) for welfare. There was no inevitability that this conjuncture would turn back to the advantage of banks. Reiner (2020) points out that British Prime Minister Gordon Brown in 2008-09 proposed to President Obama what amounted to the foundations of the Green New Deal for which Obama had campaigned in 2007. The proposal was in effect a new Bretton Woods agreement that would renew global institutions for the regulation of capitalism. Obama spurned Brown. Obama appointed Wall Street apparatchiks to key economic posts. They believed that banks should be global and capitalist in life, but national and socialist in death.

Main Street hated this and hated the Wall Street policy elite who infiltrated Washington. Their resentment sadly laid a foundation for Trump's authoritarian populism rather than Mouffe's left populism. Chapter 7 showed how Brown also favoured share acquisitions that partially nationalised private banks rather than bailouts. Obama's chief of staff opined that the state should never waste a good crisis. Sadly, as Reiner (2020) points out, it was finance capital that did not waste a good crisis, securing a stream of debt into the future that was better proofed against future crises. Left populism utterly failed to surge behind Brown at this point and to persuade key moderate conservatives like Germany's Angela Merkel against austerity. The global left at this point liked Obama much more than Brown (whom they saw as pivotal in the failed Blair administration rather than a counterpoint to it). It could have been otherwise, but the left populism of the Occupy Movement—of which 
I confess to have been a part-marching along Wall Street in 2008, made a tactical mistake in that moment to fail to mobilise behind Brown as a practical hope for Mouffean counter-hegemonic progress.

Because the upshot was the Trump presidency, more might have been lost than gained. Still, what was gained was a global reopening of the minds of econocrats to Keynesianism and the regulatory welfare state. This reopening of a Keynesian social democratic imaginary was reinforced by the Covid crisis of 2020-22. Authoritarian capitalist states like Trump's United States, Jair Bolsonaro's Brazil and Narendra Modi's India fared particularly badly for their own citizens in responding to Covid-19. Together with neoliberal states, they expanded a massive new inequality in the world system through a patent regime that prioritised vaccines for low-risk citizens in wealthy and powerful states over high-risk citizens in the least-developed economies. Semi-authoritarian, populist neoliberal regimes, like Boris Johnson's United Kingdom, likewise failed in these ways. They failed for the same reason of Hayekian aversion to state plans and state command centres ready to surge into action. They failed to save lives because of their embrace of the hollowing out rather than the strengthening of the welfare state. All these states were forced by the terrible realities of the pandemic to reverse these policies, at least partially, to more Keynesian pump-priming and the strengthening of regulatory welfare capitalism. ${ }^{3}$ This wedged more libertarian factions of their own support base to turn against their leaders. Hopefully, this will lead to policy learning during the 2020s that East Asian states all suffered lower death rates than these western states, even though they were so much more proximate to the initial pandemic take-off and at least until the end of 2021 relied on less expensive and less effective vaccines. This was because East Asian state command centres were ready to jump in January 2020for some states, with more than 100 policies in their pandemic prevention plan. East Asian societies were more educated to don their masks and had welfare states better primed to surge support for the suffering (Braithwaite 2021c). The formerly neoliberal profession of economics should find reason in the 2020s to return to a more Keynesian and social democratic dispensation if I am right in predicting that the evidence will continue to show that the states that were most ideologically Hayekian tended to fare worst in the two biggest crises of the past 15 years.

3 Similarly, more social democratic Sweden was forced to reverse its empirically misplaced hope of early 2020 that freedom and herd immunity would quickly deliver less suffering. 
Reiner (2020: 156) may be correct that a kindred crisis that will follow Covid in the next decade or two will be a crisis of the failure of liberal capitalism to deliver the antibiotics that will tame future epidemics. Vaccines and antibiotics are mostly not very profitable drugs. Big Pharma long ago shifted their research and development portfolios away from them. There are many reasons that need not distract us here. One is simply that most epidemics are like Ebola, HIV, SARS, MERS, polio and Covid-19 in that they do not experience their initial outbreaks in the western markets where Big Pharma's profits are made. Very often they are like Ebola and are tamed in unprofitable African markets before they spread to the West. When they do spread to wealthy countries, often the West tames them quickly, while elimination lags by many decades in poor countries where demand for unprofitable drugs persists.

Socialism is an important part of the solution to this problem. Excellent state-funded universities and unprecedented state research funding for Covid cures, tests and symptom amelioration strategies remarkably reduced Covid death rates as infection rates surged. At the time of writing, expectations for vaccine effectiveness are higher than the pessimistic forecasts of immunologists up to October 2020. Covid demonstrated some virtues of a strong state coupled with strong markets with vaccines that vanquished suffering (at least for the rich). It also demonstrated the flaws of western monopolisation for serving humankind in the Global South.

Basic research into cures for orphan diseases and antibiotics for diseases with insufficiently large outbreaks among rich drug purchasers will require ever more innovation supported by strong states. A minor example for most westerners, but a light on the hill for Australians, was the creation of the Commonwealth Serum Laboratories (CSL) by its government in 1916. One reason for its founding was that Australia has many of the most venomous snakes in the world and some distinctive spider venoms. Bites are sufficiently rare that there have never been profits for Big Pharma in Australian antivenoms. So, a socialist pharmaceutical corporation was established to research and produce Australian antivenoms, the CSL, in what is now the Walter and Eliza Hall Institute building in Melbourne. 'Commonwealth' was a suitably socialist descriptor for the brand. As happens when researchers undertake brilliant science with novel basic research, unexpected commercial applications also evolved. Indeed, as long as a state hedges with a high volume of intellectually plural excellence in basic research innovation, it is likely to produce a bounty of profitable science. This is what happened with CSL. 
CSL became sufficiently profitable that the state succumbed to cashing in its investment, privatising to help with the debts of the 1991 recession. CSL continued to produce a mix of profitable and important unprofitable products that saved countless lives worldwide. This continued until its latter years as a public corporation with, for example, a pioneering heat treatment to protect plasma and blood products from infection with HIV. CSL was privatised cheaply at a share price of $\$ 2.30$ in 1994 . By the turn of the century, it became the second Australian company to exceed $\$ 100$ a share. Quiggin (2020) showed that, by 2020, CSL investors enjoyed a 500-fold increase in the stock market value of CSL-10 times as rewarding as the still impressive fiftyfold increase in the value of shares in the larger privatisation of the Commonwealth Bank. Strategic socialism enjoyed underestimated profitability in countries with a well-governed public sector-profitable for taxpayers and private investors alike. ${ }^{4}$ As a private corporation, CSL produced the first vaccine for the swine flu epidemic in 2009 and became a world leader in influenza vaccines that are recommended by the World Health Organization. One of its promising current projects is a novel plasma-based compound as a therapy for acute coronary syndrome. In 2021, it was the socialism that seeded CSL that enabled Australia to have at least some industrial capability to manufacture onshore some of the vaccines needed for its citizens. Likewise, when in 1955 Dr Jonas Salk's laboratory at the University of Pittsburgh saved millions of lives worldwide by making the polio vaccine available to humankind without payment for a patent-in contrast to Covid profiteering today-CSL stood ready to produce 25 million vaccines for Australia. CSL delivered this without causing the 40,000 infections of children with polio that occurred through defective private manufacturing in the United States (Fitzpatrick 2006).

In retrospect, Quiggin (2020) is right that all the major Australian privatisations of the 1990s were underpriced. I was shocked by the breadth of this privatisation agenda in 1987 when discussion began on the Economic Planning Advisory Council. I queried fellow council members on how they would value the public health return to humankind of the invention of drugs for orphan diseases. With Qantas, I asked what the value to humankind was of Qantas as an international exemplar of

4 Between them, privatised Australian state corporations the Commonwealth Bank, CSL, Telstra, Qantas and Medibank Private are worth almost 20 per cent of the value of the ASX 200 (Denniss 2020: 11). 
safety excellence? Qantas had the best safety record of all international airlines. Perhaps that worry was misplaced because the privatised Qantas continued to enjoy that distinction.

Reiner's (2020) social democratic hero Clement Attlee was prime minister not only during the decline to the lowest homicide rates ever recorded in UK history (Eisner 2017: 580); he also delivered world leadership in safety innovation and safety outcomes with the nationalisation of British coalmines (Braithwaite 1985, 2013b). Accident fatalities had been more than 1,000 in some single years of the early twentieth century and fell to near zero per annum after nationalisation -in addition to a large reduction in the number of health-related fatalities, mainly through the elimination of black lung disease. Even so, Margaret Thatcher's privatisation of the coalmines proved to be good green policy and good fiscal policy. The social democratic imaginary is not doctrinaire on privatisation; it advocates strategic privatisations, strategic nationalisations and strategic renationalisations. A new Commonwealth pharma corporation that specialises in research and development on multiple drug-resistant antibiotics is a good idea for similar reasons to why CSL was good Labor policy in 1916. With banks, Braithwaite (2019: 557-78) made a case for less oligopolistic banking by the state investing in a particular pathway to a new Commonwealth bank to compete with the old privatised Commonwealth Bank, including socialist finance that ratchets up investment in green innovation. This might create a more competitive, greener Australian economy, with an improved capacity to ride out future financial crises. Fraudulent conduct by the major private ratings agencies before the 2008 crisis should have motivated the European Union to establish a public European ratings agency with a tough integrity charter, to compete globally with Moody's and Standard \& Poor's and to ensure higher integrity in environmental accounting (Braithwaite 2019).

Crises might open opportunities for such social democratic remedies. Reiner (2020: 16) considers, however, Michael Kalecki's (1943) warning to Keynesian social democrats that if they are too successful in reducing unemployment, lifting the wages share of national income to the point where indebtedness to banks is low and the profit share is low, to the point where unions become strong and militant, finance capital will fight back in alliance with media barons like Rupert Murdoch (and carbon barons threatened by a Green New Deal). To be fairer to the Obama presidency, this is perhaps what the Clintons were warning him about 
after they experienced such a potent conservative fightback against the modest expansion of the welfare state in their torpedoed national health insurance plan.

On the positive side of the ledger, however, Greta Thunberg-style youth are flocking to a green politics that is building resistance to neoliberalism and authoritarianism among the young. Just as Thatcher was able to scheme successfully to crush trade union movements through militarised confrontations with them, so it is possible for international unionism to reinvent itself in ways that surge back to relevance in its response to new crises. This goes to the importance of the new vision for an internationalised green trade union movement in the work of Shelley Marshall (2019).

Sweden has one of many social democratic parties around the world that has been checked and balanced by a Green Party that has been more responsive to these social movement forces. The Swedish Social Democrats were early movers in having communist unions split away from them in 1917 to form a separate communist party. They achieved the most formidable early welfare state accomplishments of any social democratic party in the middle decades of the twentieth century with a corporatist model that rejected nationalisations. Instead, they favoured negotiations between unions and business that tempered excesses in wage rises in times of inflation. Swedish business so liked this deal, and their seat at the table when it was shaped, that they became supporters of the Swedish welfare state and even its redistributive tax exceptionalism (Acemoglu and Robinson 2019: 467-74). By the 1980s and 1990s, this corporatism had become too cosy and neglectful of civil society concerns that were prioritised by neither business nor union cronies of the Social Democrats. Consequently, contestation by and collaboration with the Green Party (the coalition partner in government at the time of writing) has become a healthy tempering of the Social Democrats' model and has allowed them to respond to the decline in their vote since peaks in 1940, 1968 and 1994. The above analysis of strategic publicisations of the private is something Swedish social democracy with its Green Party partners might consider today.

Today, we have learnt that contextually attuned hybrids, which are neither total privatisation of the public nor total publicisation of the private, often serve freedom best. A purely private-sector model is not the way to conquer something like Covid-19. Publicly funded research in universities - at its foundation, in this case, by Chinese university 
research in Wuhan that made public the genetic sequence of Covid-19will always provide much of the research grunt with such big challenges. The private pharmaceutical industry will always provide most of the grunt in scaling up the production of therapeutic breakthroughs needed at great scale. Private-public partnerships with extremely heavy doses of public funding are what invented the internet, and are what works best for building new generations of aircraft carriers or putting a human on the Moon. Social democratic parties today must work with green partieswith all parties — on bold state investments with different priorities than those of hybrid socialist production by the Pentagon, NASA and NATO. They might emphasise reinventing renewable technologies at greater scale and regulatory technologies for preventing accidental wars and protecting ecosystems. It makes no sense for social democracy to return to any general aversion to privatisation nor to an ideological commitment to nationalisation of the commanding heights of economies. Social democracy must be diagnostic and open about what forms of ownership best catalyse domination reduction.

The United Nations has proved it can reduce war, thereby reducing crime and growing freedom through cheap investments in peacekeeping (Braithwaite and D'Costa 2018: 494-501; Walter et al. 2020). A United Nations that has its power tempered by the power of states is imperative to the survival of humankind and the planet. That does not mean domination by great power vetos. The next section turns to genocide as the kind of crisis such tempered power must tackle.

\section{Genocide}

Few leaders are as admired as British Prime Minister Winston Churchill. He believed that one way to win World War II was to break the morale of German civilians by pulverising their cities with carpet-bombing and firebombing. Churchill was minded to do what Hitler was not: use chemical weapons to defend the United Kingdom against a German invasion. Churchill wrote to his chiefs of staff in February 1943: 'In the event of the Germans using gas on the Russians ... We shall retaliate by drenching the German cities with gas on the largest possible scale' (Pruitt 2017). Drenching at scale would have been a crime of chemical genocide. President Roosevelt did not buy this. In 1939, he urged his allies against the approach Churchill came to execute in Hamburg and Dresden and 
to attempt in Berlin. Roosevelt said after the terror-inducing bombing of the civilians of Shanghai by Japan in 1937 and of Guernica by the European fascists:

The ruthless bombing from the air of civilians in unfortified centers of population during the course of the hostilities ... has sickened the hearts of civilized men and women ... I am therefore directing this urgent appeal to every Government which may be engaged in hostilities publicly to affirm its determination that its armed forces shall in no event, and under no circumstances, undertake the bombardment from the air of civilian populations or of unfortified cities, upon the understanding that these same rules of warfare will be scrupulously observed by all of their opponents. (Ellsberg 2017: Ch. 14)

Well before the end of World War II, the United States had abandoned this ethical stance and joined the western descent into barbarism. It embarked on a nuclear weapons program of mass civilian destruction. Hitler decided not to devote resources to this because he rightly believed that Germany's war would be won or lost before such weapons could be used. Churchill and China's Chiang Kai-shek pressured US President Harry S. Truman to use its nuclear weapons against Japan. Most Americans believe the dropping of atomic bombs on Hiroshima and Nagasaki was a terrible but necessary evil because it ended the suffering of World War II. Credible historians of World War II do not believe this today and most members of the Joint Chiefs of Staff did not believe so at the time and opposed their use. Among the distinguished American military naysayers on dropping the bomb in 1945 were Dwight D. Eisenhower, Douglas MacArthur, Paul Nitze, Carter Clarke, William D. Leahy, Chester Nimitz, William Halsey Jr and Curtis LeMay (Ellsberg 2017). The firebombing of Tokyo had killed much larger numbers of civilians than were killed in Hiroshima, instilling terror at the centre of power, so most leading US strategists and scientists involved with the bomb favoured gradual acceleration of this terror-for example, by destroying shipping just outside Tokyo Harbor with an atomic blast or just a submarine blockade.

None of this was the main game of ending the war, however. The war was about to end because Russia had begun to attack and was set to invade Japan, and Japan was poised to surrender when they did. Truman did not want this to happen, and the atomic bomb was aimed at deterring the Soviets for the purposes of the impending Cold War as much as or more than deterring Japanese civilians. Criminologists of war crimes 
have contributed nothing to moving NATO's opinion away from the view of nuclear weapons as the necessary evil that ended World War II. Hiroshima and Nagasaki were war crimes directed at civilian terror, contrary to President Roosevelt's more ethical plea of 1939. Since then, US and Russian presidential criminality has worsened and deepened. US presidents became inured to threatening other countries with complete destruction of their cities. If international courts rightly found the events in Srebrenica and Rwanda to be genocides then threats of nuclear launches with contemporary warheads threaten much more massive civilian genocides. Indeed, what all nuclear powers-including smaller ones like the United Kingdom, France, Pakistan, India, Israel and North Koreathreaten against their enemies by pointing their nuclear arsenal at them is a genocide of larger proportions than Hitler perpetrated in World War II.

A distorted noble narrative of World War II is that the Allies fought it to end a genocidal regime. On the ashes of that victory, the Allies built a world order based on mutual threats of genocide, even a 'doomsday machine' on both sides, which guaranteed genocidal responses to any nuclear attack (Ellsberg 2017). Progressive American criminologists can be comfortable with allegations that George W. Bush was a war criminal, but they are not always comfortable when it is said that Clinton, Obama and Biden ruled and defended a world order based on mutual threats of genocide against all other societies, including non-nuclear states who renounce such threats as criminal.

\section{Preventing genocide-ecocide cascades}

Even nuclear wars between lesser powers like Israel and Iran, Pakistan and India, North Korea and China could all cascade to be ecocidal in their environmental impacts. We have seen how cyberwarfare or cybercrime that is intended to disable a satellite that targets conventional missiles might accidentally and coincidentally disable an entire nuclear arsenal (Ellsberg 2017; Beebe 2019; Perry and Collina 2020). These expert strategic authors explain how this might cause an imprudent state, fearing loss of its nuclear defences, to use them rather than lose them to their wrongly presumed enemy. Braithwaite and D'Costa (2018) show that there are strong tendencies for economic crises to cascade to wars, be they crises of mass unemployment or hyperinflation. Or the problem can be the likes of a slightly unhinged Pakistani general who once said Pakistan would interpret an inexplicable crash of the stock exchange in Karachi 
as an act of war by India. Further, Chapter 7 argued that nuclear war between Pakistan and India might cause a real global economic crisis and a climate crisis. If a catastrophic political crisis between India and Pakistan happened to coincide with a stock market crash and an environmental tipping point, perhaps no power could hold back a global crime-war cascade. Risks that might cascade from cybercrime to nuclear alerts are not reducing if it is true that China has been contracting cybercriminal organisations at scale to hack the West, and Microsoft specifically (KannoYoungs and Sanger 2021).

When pandemics break out in the aftermath of mutual cascades of ecosystem collapse, economic collapse and nuclear war, few of the most powerful states on the planet would be left with the logistical capability to combat a pandemic in the way they did in 2020 and 1918. Cascades from ecosystem collapse to diseases that jump from animals to humans are already increasingly common because of surviving wild animal populations being crowded to live closer to humans. In Australia, several new viruses have afflicted humans as a result of deforestation driving bats to refuge in the trees of urban parks, and after the bats themselves became more susceptible to disease because of ecosystem crises that afflicted their health. Anomic collapse of freedom might occur everywhere after a nuclear war. All this is an unknowable, unpredictable risk of crisis cascades. Yet it is not too late to reinvent capitalism, to reinvent environmental diplomacy and war diplomacy, to regulate cybercrime and AI that overreaches or goes awry. A coincidence of these kinds of catastrophes can then become an event of low likelihood.

My contention has been that while criminology does not bear the main responsibility for finding alternative paths to regulate the planet, it has a more important part to play than it has had the vision to see. This is because the fabric of prevention of cascades of crises has many strands. Some of these are better understood by economists or international relations scholars, but many strands are best understood by criminologists-for example, the corruption of regulatory institutions, the criminalisation of states, cheating within markets in virtue designed to temper markets in vice and cybercrime that coincidentally cascades to nuclear weapons being put on alert.

Chapter 7 argued that much can be done to increase welfare and wages to prevent crises of insufficient demand and to keep markets pumping during crises. Inspiring regulatory initiatives can be launched to strengthen 
the self-incapacitation of toxic corporations and of states armed to the teeth with weapons of mass terror. It is possible to shift the shape of economies so they stoke demand while softening their environmental impact. In the medium term, economies can be reshaped so that jobs are created less by investment in the production of material things than by growth in human services. Shifting the shape of the economy so more of the jobs are for nurses, teachers or carers reduces emissions (Denniss 2017; Burford et al. 2019). Financialised capitalism pushes workers and whole economies into levels of debt they cannot manage when crises arrive. Understanding these dynamics helps us grasp why authoritarian capitalist economies accomplished a wider economic growth lead over liberal economies this century and, in the case of China, a lead in green innovation (Drahos 2021; Braithwaite 2020a). This is a different pattern from previous centuries. Investing in more jobs to steer capitalism and expand welfare sits alongside creating more jobs in human services as an imperative to avert cascades to ecological, security, health and economic crises, and to authoritarianism. While there is enormous path-dependence of momentum towards extinctions, it might be countered by strategies for mutual interpenetration of growth path-dependencies among institutions of the market, welfare and regulation (Braithwaite 2021a).

Green growth is possible for an economy that consumes more of the services of aged care, childcare and disability care workers, doctors, nurses, educators, regulatory inspectors, UN peacekeepers and serving staff. Care workers do not burn carbon in the way factory workers do. If growth can be fuelled by further accelerating the shift to a services economy, driven in part by growing the welfare state, growth can be green. Likewise, debt that funds investment in renewables is economically fertile debt for growing an economy. A state that ran up debt by investing in expanded secondary or higher education during the 2010s borrowed at interest rates less than one-third of the return to GDP of increased investment in education (Psacharopoulos and Patrinos 2018); this differential widened after Covid. Taxes can be increased to improve education, health and welfare benefits. This helps green growth in economies that can allow lower taxes at a future time when the nation collects dividends on that social investment.

Likewise with welfare investment in modest but secure housing for the poor or regulatory investments that prevent disruptions in access to housing. Recovery programs for the hugely expensive burdens on states of alcoholism, addiction to illicit drugs and recovery from crime and prison are less likely to succeed with people who have insecure housing-so 
much so that secure housing is part of the scale to measure recovery capital (Best et al. 2012; see also Cano et al. 2017). Welfare state investment in secure housing for all can enhance the effectiveness, and the growth dividend, of all investments in the welfare state. This conclusion will not pile on more examples that go to the feasibility of markets that flourish because the shape of economies is shifted away from the consumption of large cars, large houses and corporate towers of big offices overflowing with consumer durables, fast furniture and fast fashion. A hegemonic shapeshift of this kind is beginning in the world's largest economy, China, where services consumption and health, welfare, education and regulatory workforces are all growing steeply (Braithwaite 2020a). While China is still by far the world's largest emitter of carbon dioxide, a steeply growing proportion of its factory production is in producing most of the world's electric cars, solar panels, wind turbines and other essentials of global carbon-neutrality. If China can shapeshift as part of its UN commitments to halve its emissions this decade, perhaps hegemonic shapeshifts are not beyond western economies.

\section{Agonistic social movement model- mongering}

Nonviolence is the ethos of protest politics critical to effectiveness and freedom. Activists need the wisdom to see that social movements are better able to ride waves of history than to create them. Opportunities to think cleverly about how to do this will be more frequent as existential crises press perilously upon us. Events like Australia's mega-bushfires of 2019-20 drove a substantial shift away from recalcitrant Australian climate denial on the backs of the three billion vertebrates that perished. Such events will recur more frequently. Waves of political unrest that are directly connected to climate change and drought in the manner of the Australian bushfires are just one kind of wave of history to ride. While the risks of a nuclear power plant meltdown have greatly reduced, one day there will be another Chernobyl. We have seen that global pandemics create another opportunity that social movements mostly had no strategy to ride. They, too, are historically common; modernity has seen dozens, though most in the recent past have not hit the West in a devastating way. HIV/AIDS and polio in the late and mid-twentieth century had health, though not economic, impacts of a scale that compared with Covid-19, with enduring and devastating impacts on young survivors. For several 
African countries, Ebola was also tragic this century. Economic crises that result in recession or hyperinflation are even more common; the past eight centuries have seen 350 of them (Reinhart and Rogoff 2009).

Then there are micro-events that erupt into waves of history; a poor man in Tunisia self-immolates after a last straw of state oppression, catalysing the Arab Spring to cascade across a dozen countries. The killing of George Floyd by Minneapolis police in 2020 sparked a wave that surged anger and sorrow across 51 US states and dozens of other countries.

Environmental activists are no less in denial than the rest of the community. They are similarly unprepared to ride the wave of environmental concern that will arise when a city like Tokyo, Beijing, Pyongyang or New Delhi is erased in a never-before-seen cloud that rises into the atmosphere as a result of the failure to dismantle the reckless nuclear weapons programs of North Korea, Pakistan or, worse, Russia, or some other country. My fear is that our grandchildren are quite likely to see something like this happen during their lifetimes or that of their children. A random spark like the political assassination of a president in Taipei, Beijing or Washington might cascade risk. We know this because war happens in response to such sparks in defence strategists' war-gaming and scenario simulations of escalations (Allison 2017: 155). We prudently fear this because in the past great powers often got into wars they never wanted, and genuinely worked to avoid, in response to sparks like the assassination of Archduke Ferdinand of Austria-Hungary (Clark 2012).

Does the social movement against climate change really have contingency strategies in its top drawer that result from its scenario planning (as opposed to that of state defence ministries) about how to ride the kind of climate crisis wave induced by a nuclear war? History instructs us about what happens when social movements have failed to do their scenario planning well with much less dramatic events than a nuclear weapons exchange. Martin Luther King was strategically wise about the greater power of nonviolent compared with violent social movement politics. He was central to building an effective civil rights movement in the 1960s with Gandhian strategies. He predicted his own assassination privately to his colleagues and even publicly. When he was assassinated, this sparked a great wave of protests that saw many US cities in flames. The nonviolence of the uprising was poorly managed by an unprepared social movement. Cascading riots, looting and killing opened the door to Richard Nixon to win the 1968 election on a racist platform of law-and-order politics. 
The wave of mobilisation that swelled after the murder of George Floyd was better harnessed by the Black Lives Matter movement. Instead of the forces of violent protest progressively displacing nonviolent protest (as occurred in the 1960s), in 2020, the forces of nonviolent protest were well enough prepared to progressively displace the politics of violence and this in turn helped close the door on the authoritarian law-and-order presidency of Donald Trump. Even so, the Black Lives Matter movement was not as prepared as it might have been for armed right-wing racists who enjoyed encouragement from President Trump to act as provocateurs of violence on the streets. The early tide of political resilience of nonviolence turned and the political advantage seesawed back towards Trump for a worrying period in late 2020. Scenario planning in social movement politics could be more detailed, resilient and nimble.

We can learn to make agonistic pluralism more diagnostic of when protest subdues violence, expands freedom, escalates violence and advances domination. The largest Arab Spring movement in Egypt surged liberal democrats and leftists, but it was captured by the Muslim Brotherhood, who swept to power electorally because they were better organised and had an organisational power base spread throughout the nation. The Muslim Brotherhood had done their scenario planning during their years in prison about how to swoop at that moment of regime weakness. The lesson of history is that they executed it well, even if they failed to hold their capture of the state against the return to power of militarised authoritarianism. In Syria, most Arab Spring protesters were also peaceful and progressive, but they, too, were outflanked by opponents of the regime who were committed to violence, to Islamic State and to Al-Qaeda. Again, the proponents of violence and domination had better organisational power bases, better scenario planning that they had gamed in their preparation and wealthier international support networks that were ready and waiting. The tragic outcome was half a million lost lives and a more militarily muscular Syria, Iran and Russia.

These Arab Spring failures repeated the failures of the Iranian Revolution of 1979, which was also mostly led on the streets by liberal democrats and leftists. But the ayatollahs were the ones who had the powerbases in the mosques and the Islamic educational institutions and who put the socialists, the liberals and the political leaders of Kurds, Arabs and other oppressed minorities of the revolution in prison. The 2009 Green Revolution, when millions of opponents of that Iranian regime occupied Azadi (Freedom) Square, was full of promise to overthrow the ayatollahs. 
The leaders were inadequately prepared university intellectuals who failed to mobilise the marginalised ethnic minorities; they elected a committee in the square that foolishly advised the assembled millions to go home while they met to formulate a strategy to put to them the next day. As they made their way in small groups back to Azadi Square the next day, the security forces were able to pick them off, shooting, arresting and dispersing them. The uprising was over. ${ }^{5}$ Social movements for transformation stand little chance if their adversaries do crisis scenario planning and they do not. Agonistic pluralism is a politics of riding waves of history with organisational bases and scenario planning. It is about being a modelmonger, with most of your transformational plans for a moment of crisis waiting in the top drawer, a few others on the backburner, with all activist energy shifting to the front-burner a plan that is responsive to today's crisis (Braithwaite and Drahos 2000: Ch. 25).

Neither Mandela, Gandhi nor Gusmão in Timor-Leste totally renounced violence. What they demonstrated is that violence is the tool that favours the masters; a switch to nonviolence as their strategy of struggle increased the prospects of success for the dominated. Chenoweth and Stephan (2011) showed this systematically across 323 political struggles for maximalist transformation (such as regime change) since 1900. Nonviolent struggles were twice as likely to achieve most of their objectives in the long run compared with armed struggles. Their research also reveals that violent victories against domination are more likely to create dominating, undemocratic successor regimes (Braithwaite and D'Costa 2018: 59). This book advances further reasons why committing to nonviolence is committing to freedom. Braithwaite and Drahos (2000) showed that in global campaigns to regulate business domination, webs of dialogue were more valuable to the weak than to the strong, while webs of reward and coercion were more valuable to the strong than to the weak. This was not, however, full vindication of Lorde's (1984) 'the master's tools will never dismantle the master's house'.

Chapter 7 found social movement politics to be recurrently effective by turning the masters' tools against the masters. Adept social movements enrolled business organisations to defect to their projects (Latour 1986). The first great social movement was one of the most successful for this reason. The social movement against the slave trade in the eighteenth and

5 This interpretation is based on Peacebuilding Compared interviews with uprising leaders in Iran, Iraq and across the diaspora. 
nineteenth centuries was nonviolent. Church leadership in England was particularly potent in mobilising electoral support for parliamentarians who supported bills to ban the slave trade and for causing those who opposed them to lose their seats. After this campaign succeeded in the United Kingdom, British business and the British state had a strategic trade interest in persuading other states to join a global ban (Chapter 7). British naval domination pursued the ban violently at times, blowing slaving ships out of the water in the Harbour of Rio de Janeiro. Likewise, we saw that after the US environmental movement succeeded in its campaign for a legal ban on CFCs because of the ozone hole they were opening, DuPont responded by inventing CFC-substitute technology. DuPont and President Reagan then decided they had a strategic trade interest in licensing DuPont's technology to the rest of the world. Then Reagan and his diplomatic corps became the most unlikely climate wolfwarriors the world has seen, but also the most successful, in implementing the Montreal Protocol on Substances that Deplete the Ozone Layer. This is what is meant about the power of enrolling the masters' tools to divide and conquer the masters. Activists must be politically honest about the fact that bad power cannot be defeated without broad alliances for good power. When allies are masters who use the masters' tools, the principled social movement must be clear that these are the masters using the masters' tools, not the movement's tools, but reap the benefits of their use nevertheless.

\section{Rebalancing postwar social democratic virtues}

The great powers, the United States and China, each interpreted the failures of the other in response to the 2020 Covid crisis as evidence of the weaknesses of the social and political systems of the other. Both were right to contend that we live in an era when crises are more globalised. In a world that has become tightly coupled, the globalisation of economies, of disease, of environmental crises and of war are all global risks. The West tends to credit the long peace between great powers since 1945 to nuclear deterrence. Russian analysts think differently. They see plenty of fellow analysts on both sides who contemplate ways of surprising the enemy to win a nuclear war. But Russian belief is that great powers are unwilling to gamble on winning, because after a nuclear exchange their logistical 
capabilities would be so depleted they would lack the capability to mobilise an army to capitalise politically by pacifying a massive society in another hemisphere (Chekov et al. 2020: 32).

For this to happen, a victorious army would have to arrive and restore a desired order in a defeated country. In the Russian view, however, to support large-scale long-term activities in another hemisphere is practically impossible (Kosolapov 2008).

My addendum is that a country weakened as a decisive nuclear war winner might struggle to contain the epidemics that historically so often plague continents after huge wars. The nuclear war winner's economy might lose out to a third power that is less devastated by the nuclear exchange.

China and the United States were right in their critiques of each other's systems in their Covid responses. The US was right to castigate China for a cover-up and the failure of its institutions of science and transparency to be independent in sounding the alarm to the world in a timely fashion. China was right to allege that the United States lost a hundred times more lives than China because its hollowed-out state lacked the institutional capacity to respond adequately to a crisis it knew in advance was coming.

But these were not the only two systems that were tested by this conflict. Eastern hemisphere economies-from more liberal ones like New Zealand, Australia, South Korea, Taiwan and Japan to more authoritarian ones like Vietnam, Cambodia, Malaysia and Singapore-performed much better. The latter group may not be transparent about the vices of their ruling parties, but, as the World Bank's 'Asian Miracle' report pointed out long ago, even the most authoritarian tiger economies are surprisingly transparent in allowing the contestation of evidence and public policies, as long as these do not threaten governing families and parties. They were transparent about Covid-19. Their states and civil societies were prepared to deal with it, and they pulled the levers to prevent its spread before it cascaded out of control. Those countries closest to the original outbreak, including China's neighbours Taiwan, Vietnam and South Korea, were among the countries that fared best during Covid's first year at containing the pandemic for these institutional reasons.

Their Third Way was not that of Tony Blair's or Bill Clinton's hollowing out of the state under a social democracy false flag that was in fact captured by finance capital and patrimonial capitalism (Piketty 2014). The most successful western government in its management of Covid, however, so 
far has been Jacinda Ardern's in New Zealand. Crisis responsiveness there was rapid, decisive and impeccably transparent. It was the first country to achieve first-wave elimination of the virus within its borders. In the 1980s, New Zealand became infatuated with the neoliberal Washington Consensus, which lasted many years. Ardern's New Zealand has moved to a hybrid of rediscovering old virtues of Keynesian social democracy and newer virtues of the Asian tiger economies, but with wider transparency, stronger commitment to evidence-based policy and less domination than these traditions of governance.

To a degree, all countries were forced by the imperatives of managing Covid to become more like New Zealand. Even China was forced by international scrutiny to become more transparent, opening itself to data collection by foreign medical scientists. Even the United States was forced to consider state 'planning' of the economy as no longer a dirty word. The Trump and, more so, Biden administrations opened up to Asian tigerstyle capability to ensure that for this crisis, and the next, they had enough strategic industrial capacity to reverse deindustrialisation, at least to the point where it could rapidly scale up the personal protective equipment, ventilators and vaccines that were central to the crisis response.

\section{Learning macrocriminology lessons from macroeconomic failures}

Covid-19 is not the only crisis that has shifted policy thinking about the imperative for strengthening more diverse and tempered institutions. The economics profession, which-in the footsteps of Hayek, Robert C. Merton and Thatcher-supplied the ideas that fuelled financialised capitalism ruled by money politics, is still divided. Yet it has seen widespread changes of heart. Many economists now favour moving away from the radically privatised US health system of high-quality (but expensive) health care for the rich and early death for the poor. They favour tax collection that repairs hollowed-out state infrastructure, from health to highways, bridges and schools. Many agree with Piketty's (2014) interpretation of the evidence that requiring the rich to pay more tax will not significantly reduce incentives to work, though that continues to be contested. The most dramatic change is that most economists today see a strong evidence-based case for higher wages, especially for the poor, to sustain demand and temper indebtedness. The evidence no longer 
supports their former belief that upwards movement in the minimum wage increases unemployment (Quiggin 2019: 251-54). It is hard today to find economists in China or the United States who think that fighting wars is in the national interest because they drive creative destruction of unresponsive production systems (Quiggin 2019: 125-28).

Some of the privatisations of this era were good policy; others were not. The global movement to deregulate state price-setting in aviation markets and privatise national carriers has delivered cheap, safe flights for cut-price travellers. During the highwater mark of neoliberal thought, however, buyers of underpriced privatisations made large political donations or bribed public officials, particularly in Eastern Europe. Economists came to see it as a paradox of late twentieth-century privatisations that a hollowedout state inadequately regulating privatisations delivered economically irrational, criminogenic, monopolistic and anti-freedom privatisations.

Remarkably, criminologists had little interest in warning against this outcome, nor in advocating regulatory reforms on the back of these corruption disasters. Russian President Vladimir Putin was the actor with the imagination to 'never waste a good crisis' by sweeping to power to clean up the oligarchs.

What these recent hegemonic shifts mean is that it is no longer pointless to advocate tougher regulation of corruption, of the military-industrial complex, financial capital, antimonopoly laws and environmental protection and tougher taxation of capital and the wealthy, more relentlessly responsive tax enforcement and street-level enforcement by labour rights inspectors who enable significant re-unionisation and globalisation of a living wage, following Marshall (2019) on how to deliver this.

Strengthening trade unions and regulation of labour standards as a strategy of redistribution and empowerment are a good case study of disenchantment with a tired old social movement that can be reversed. This is not politically utopian. Political centrists like Bill Clinton and Tony Blair in some ways sustained and even strengthened the antiunion reforms of Ronald Reagan and Margaret Thatcher. We can now see trade unions again as one of the transformative and earliest global social movements. We can reconsider their decline as not inevitable, but contingent and reversible. As Quiggin points out, unions had terrible decades with the global inflationary upsurges of the 1960s and 1970s: 
In retrospect, it is clear that the acceleration of inflation was primarily the result of mistakes in macroeconomic policy. At the time, however, it seemed more plausible to place the blame on [a] wage-price spiral caused by the greed of unions and big corporations, acting in concert. Because the process of keeping wages ahead of inflation required virtually continuous strike action, unions came to be seen (and to some extent to see themselves) as being in conflict with society as a whole. By contrast, attempts to control increases in prices, most notably during the Nixon wage-price freezes from 1971-73 ended in ignominious failure. (Quiggin 2019: 246)

As Reiner (2020) explained, crushing union power was also a conscious strategy in the way Thatcher worked with the Murdoch press to militarise the suppression of the miners' strike (Green 1990). Prime Minister John Howard in Australia deregulated labour law on the back of crushing the maritime union's strike. Union corruption and capture by organised crime further undermined union legitimacy and played into the hands of conservative conspiracies against unions. Royal commissions into union corruption became a stock in trade of Australian conservatives.

Second-wave feminists abandoned the unions that first-wave feminists had embraced in mutually beneficial networking because unions had been so incorrigibly patriarchal. That situation has recently radically reversed in some societies such as Australia, and indeed globally at the International Confederation of Free Trade Unions. This is necessary when the most oppressed unionised workforces are feminised. This book has argued that feminism is a social movement that is important to so many of the tributaries of reform proposed for a low-crime, low-domination society. Gender equality is a fundamental macrocriminological strategy for suppressing crime-war cascades (Braithwaite and D'Costa 2018: 525-26). Its potential might not be fully realised without returning to an alliance with feminised trade unions and welfare rights movements.

As Quiggin (2019) points out, casualisation and labour law deregulation can be repealed. Many workers crave the protection of unions but are simply afraid to sign up because they will be victimised by employers who should be prosecuted for such victimisation. Marshall's (2019) vision for how to accomplish this globally, and how to transform and reboot a globalised union strategy, is an inspiring one. 
Some will question whether such economic policy analysis has much to do with criminology. Macrocriminology might learn from Keynes and New Deal macroeconomics. The austerity of the 1920s and 1930s that it displaced was at its worst in Weimar Germany and Japan; this was a macroeconomics of hyperinflation and mass unemployment that was causally implicated in the worst crimes of human history that threatened freedom globally. The world, and even Ronald Reagan's Republican Party, learnt from Keynes and the New Deal that incurring state debt to pump up employment is a better response to recession than austerity. The world applied that lesson somewhat to the Global Financial Crisis of 2008, but not well enough. Return to neoliberal austerity was too rapid, especially for countries like Greece. With the Covid recession of 2020, again, even the US Republican Party learnt that second lesson. The learning was from qualitative, historically and macro-theory-informed, evidence-based macroeconomics.

\section{A world of better macro-settings}

What criminology might ponder from its shared experience with the macroeconomics of violence is that criminology would do well to crave and craft its own historically and theoretically informed macro imagination. Ways to do this could include the proposals listed in Appendix I.

Appendix I is the book's actual conclusion. The conclusion to this chapter asks readers not to be dispirited by its warnings that the challenges of freedom and crime are complex and fraught with hegemony that repeatedly trumps liberation. It cannot be said that freedom and crime are variables that all societies have in similar measure. Today's freest societies have periods of great domination in their histories. Just as the differences in domination between the most and least free societies today are huge, the differences in crime are more than 100-fold between the highest and lowest by society, neighbourhood and period of history.

Cornucopias of micro-measures like better drug rehabilitation cannot eliminate 99 per cent of crime and domination on their own. What this book argues is that macro transformation can and does. That level of elimination is what 100-fold differences mean. In Congo for the past 30 years, rates of murder, rape, the burning of homes and looting have easily been a hundred times as high as in Germany. But, during the Thirty Years' War, Germany was rather like the Democratic Republic of Congo 
of the past 30 years in terms of crime and domination (and probably worse; see Chapter 3). One need not go back that far. When the Soviet army was sweeping across Germany in 1945, following Stalin's advice to rape women and take what they needed, domination and crime were not so greatly different from the Thirty Years' War. Germany's recovery from its postwar anomie, violence and domination was as rapid as Congo's descent into it. My thesis is that Germany was able to conquer crime and domination because it made a good fist of making the 150 tributaries of Appendix I flow into six rivers of freedom. Today, Germany CHIMEs with intertwined varieties of capital; it is rich in the collective efficacy to secure order and freedom; its institutions are strong, variegated and relatively autonomous. In recent years, even its institutions of finance have been somewhat tempered. Still, it can do much better. Indeed, many countries do better than Germany on almost all 150 of freedom's tributaries.

Germany did not need as much help as Congo, but it got more help than Congo will ever get, through the Marshall Plan-the finest moment of the American century. I have shown strong evidence that postwar peacekeeping and peacebuilding do work in helping societies to CHIME and conquer domination, war and crime. As the Montreal Protocol and the regime for oil pollution at sea have shown (Chapters 6-7), environmental agreements can and do work. There is no inevitability of ecocide. I have argued that the risks of nuclear genocide would be many times worse without the nuclear nonproliferation regime, even within the depressing limits of its regulatory capabilities. Anti-domination politics is politically rewarding, even though hegemony recurrently trumps liberation. 
This text is taken from Macrocriminology and Freedom, by John Braithwaite, published 2022, The Australian National University, Canberra, Australia.

doi.org/10.22459/MF.2021.12 